\title{
The Calculus of Public Corruption Cases: Hidden Decisions in Investigations and Prosecutions
}

Journal of Criminal Justice and Law: Official Journal of the Law and Public Policy Section of the Academy of Criminal Justice Sciences Volume 3, Issue 1, pp. 22-37 (2019)

\section{Kristine Artello and Jay S. Albanese I}

\begin{abstract}
Acts of public corruption can undermine the rule of law and the legitimacy of the state. Holding public officials to the rule of law through the threat of prosecution is a crucial mechanism to give the law meaning in practice. In the United States, nearly all prosecutions for public corruption occur at the federal level, although many defendants in these cases are officials at the state and local levels of government. When corruption cases are brought, they usually result in a conviction via a guilty plea. However, making these cases is difficult, with only about a third of investigations resulting in actual criminal prosecutions, an outcome much different from those seen in white collar or organized crime cases. In this study, we seek to elicit the decision-making processes that occur in corruption investigation and prosecution. On the basis of 40 interviews with former investigators and former prosecutors, it has been found that experience, access, resources, and institutional barriers are all challenges to successful investigations. At the prosecution stage, prosecutors face a somewhat different set of barriers, including implied legitimacy concerns, thresholds, and potential long-term repercussions. Implications of these findings for policy and resources are discussed.
\end{abstract}

Public corruption is the misuse of one's public office and/or authority, either an elected office or appointed position, for personal gain (Rose-Ackerman \& Palikfa, 2016; Transparency

\footnotetext{
' L. Douglas Wilder School of Government and Public Affairs, Virginia Commonwealth University, Richmond, Virginia, USA

Corresponding Author:

Kristine Artello, L. Douglas Wilder School of Government and Public Affairs, Virginia Commonwealth University, Richmond, Virginia, 23284, USA

E-mail: kartello@vcu.edu
}

The authors wish to express their appreciation to the blind reviewers of the original manuscript for their comments, which were helpful during preparation of the final version of the manuscript. 
Journal of Criminal Justice and Law

International, 2017; World Bank, 2017). These acts of public corruption can undermine the rule of law and breed public distrust of government, thereby eroding the legitimacy of the state. Holding public officials to the rule of law is crucial to make prohibitions against public corruption meaningful in practice, but public corruption cases are not easy to make. In the United States, the vast majority of prosecutions for public corruption occur at the federal level, although many defendants in these cases are state and local government officials (Cordis \& Milyo, 2016). When Cordis and Milyo searched newspaper articles for public corruption convictions over a 30-year period, they found that only $5 \%$ of the cases had occurred outside the federal courts. Consequently, it is through the federal U.S. Attorneys' offices that decisions surrounding public corruption prosecutions occur, with the oversight of the Department of Justice Public Integrity Section in Washington, DC.

Much of the existing research surrounding U.S. Attorneys' decision making examines case level data to determine the influences of partisan politics (Beale, 2009; Pavlik, 2017; Gordon, 2009), available resources (Alt \& Lassen, 2012), and priorities (Johnston, 2010). Because most of the decision making occurs away from the public eye, however, it has been difficult to ascertain the motivations behind prosecutors' decisions. This article seeks to shed light these low-visibility decisions and the influences behind the investigations, declinations, and prosecutions of public corruption cases.

\section{LITERATURE REVIEW}

Research has examined public corruption convictions, and the number and types of behaviors prosecuted. In the last 30 years, the number of public corruption convictions has steadily climbed from under 290 in 1986 to over 410 in 2001 (Albanese \& Artello, 2018; Albanese, Artello, \& Nguyen, 2019). In 2002, a reduction occurred in the number of public corruption cases (which may have been related to the shift in investigative and prosecution resources to focus on terrorism). After 2002, the trend in public corruption generally continued upward. The primary behaviors underlying public corruption prosecutions and convictions over the last 30 years include the following: fraud or misuse of government funds, bribery, extortion, and conspiracy or racketeering (Albanese et al., 2019; Center for the Advancement of Public Integrity, 2017). At the state and federal levels, where fraud by public officials is the most common type of corrupt conduct, exploitation of government procedures or misuse of authority can occur in large procurement, contracting, and regulatory processes (Roebuck, 2016; U.S. Department of Justice, 2017). However, the Department of Justice defines public corruption cases as including all cases in which public officials use or abuse their position for personal gain, as well as all cases in which individuals defraud a federal program, such as Medicaid, even though no public officials are involved (U.S. Department of Justice, 2018).

Prosecutorial discretion has been the subject of much discussion and debate, and most of the debate has focused on decisions about formally charging suspects and plea bargaining (especially in cases involving sexual assault and discrimination against minority defendants), and about sentencing recommendations. The work has found that these low-visibility decisions are not subject to review and therefore are made with little in the way of oversight (Bushway \& Forst, 2013; Hartley \& Tillyer, 2018; Kutateladze, Andiloro, Johnson, \& Spohn, 2014; Spohn, 2018). Such 
lack of oversight results in broad discretion that is not systematic and that depends on the preferences of local prosecutors.

In corruption cases, however, the situation is different because the overwhelming majority of corruption cases are made at the federal level, and these are subject to central review by the U.S. Department of Justice Public Integrity Section (Cordis \& Milyo, 2016; Albanese et al., 2019). As a result, systematic oversight of public corruption cases exists in the United States to ensure that only significant cases with strong available evidence are prosecuted and reducing the possibility of the unwarranted use of discretion by prosecutors.

Research has examined political influence on public corruption prosecutions. The discussion concerning political interference with public corruption prosecutions started soon after nine U.S. Attorneys were fired during the first term of President George W. Bush (Lawson-Remer, 2009). According to press reports, these individuals were fired because they were not viewed as loyal and to make room for "loyal Bushies" (Lawson-Remer, 2009, p. 1290; Gordon, 2009). In a similar way, Preet Bharara, U.S. Attorney for New York (Southern District), was fired by President Trump after he refused to take the president's telephone calls, according to Justice Department protocols (Haberman \& Savage, 2017).

Before Skilling v. U.S. (561 U.S. 358, 2010), prosecutors had leeway in bringing corruption cases forward under the honest services fraud statute, which permitted prosecutions for bribery and failures to disclose a conflict of interest that resulted in personal gain. The statute allowed wide discretion at the point of investigation and declination decisions (Lawson-Remer, 2009). However, the U.S. Supreme Court redefined the parameters of honest services fraud to bribery and kickback schemes exclusively and did not explicitly address undisclosed self-interested deals (Becvar, 2013; Roberts, 2012). As a result, it became more difficult to prove bribery-related corruption cases without proof of an explicit corrupt agreement between a public official and the bribe givers or receivers. This shift presents a significant issue for prosecutors because bribery is the most common form of corruption (Albanese et al., 2019).

Measuring potential political influence into prosecutorial decisions has been difficult. Pavlik (2017) examined public corruption cases in politically important states to determine whether political influences impacted prosecutions. In the study, those states that saw an increase in public corruption convictions were the ones that were important during a presidential election. However, other research has not found any significant differences based on political parties in the executive branch. Gordon (2009) compared cases from the Clinton era (1993-2001) with cases from the G. W. Bush era (2001-2009). Under Clinton, the sentences defendants received were 6 months longer than those imposed under Bush. Additionally, it was found that during the Bush administration, some U.S. Attorneys targeted Democrats, but both Clinton and Bush pursued cases against Democrats at state and local levels (Gordon, 2009). One way to explain these differences is that when a party is power, then that party is the one with greater opportunities to exploit openings for corruption. In other words, individuals in the minority party do not have the opportunity to commit corrupt acts until they have the power (i.e., political office) to enact policies or approve contracts as public officials. As more Republicans have taken control of state and local legislatures and offices in recent years, more public corruption cases will likely focus on Republican candidates, if this explanation is correct.

Research also indicates that resources (Alt \& Lassen, 2012) and organizational culture (Carpenter, 2001; Gordon, 2009) influence public corruption prosecutions. Alt and Lassen (2012) 
Journal of Criminal Justice and Law

compared jurisdictions and prosecutions by type of case and number of attorneys to determine whether more attorneys produced more prosecutions. They found that the addition of one more attorney to an office led to an increase in the number of corruption prosecutions of slightly more than $50 \%$ (Alt \& Lassen, 2012). After the firing of the nine U.S. Attorneys, several reported that their dismissals had been due to their defense of the agency culture and norms to resist political forces in the new administration (Gordon, 2009). U.S. Attorneys are appointed by the president, so when a president from a different party is elected, it is difficult to distinguish between routine political patronage appointments and appointments resulting from undue political influence on prosecutors (Savage \& Haberman 2017).

When U.S. Attorneys consider whether to prosecute a case, they consider the complexity of the prosecution, the priorities of the office, and the likelihood of success-because their performance evaluations depend on conviction rates (Alt \& Lassen, 2012; Ramirez, 2013). Public corruption, white collar crime, and organized crime cases face similar considerations (Gottschalk, 2016; Sanyshyn, 2017; Singh, Catsambas, Flynn, Kot, \& Mayo, 2017). These concerns include complex litigation, skilled defense attorneys, and the frequent involvement of multiple parties (McGuire, 2011). White collar crime and public corruption also share the implied legitimacy of upper-class individuals, who usually are without any prior involvement in the criminal justice system (Gottschalk, 2016). Consequently, examining how U.S. Attorneys' offices prosecute the various types of complex crimes versus other types of crimes (e.g., street crimes) may provide insight into public corruption cases.

The research on prosecutorial discretion has focused on outcomes as measured by charged offenses, declinations, convictions, and sentences, contrasted by political party. Additionally, available resources and evaluations may influence the prosecutions. However, current research on the actual prosecutorial declination behavior of U. S. Attorneys is lacking because this behavior is generally invisible. Only in the last few years have prosecutors announced their reasons for failing to indict a person (Weiser, 2017); however, such announcements are made only when the public is aware of the investigation or the activity that gave rise to an investigation. Many public corruption cases generally fall outside these parameters. Furthermore, research on U.S. Attorneys' perspectives on their own decision making is lacking. This article fills the gaps by examining data on prosecutorial declinations and interviewing former U.S. Attorneys, assistant U.S. Attorneys, and former federal investigators to understand the decisions made regarding the declination or prosecution of public corruption cases.

\section{METHODS}

This study examined both quantitative and qualitative data from two difference sources. Statistical data on public corruption referrals, prosecutions, and convictions over time were obtained from the Transactional Records Access Clearinghouse (TRAC) and analyzed with SPSS Software. In addition, in a grounded theory approach (Cresswell \& Poth, 2018), interviews were conducted with former prosecutors and investigators $(\mathrm{N}=40)$ to elucidate the patterns found in the statistical analysis.

TRAC is a data gathering, data research, and data distribution organization at Syracuse University. TRAC systematically collects and verifies government agency data according to the Freedom of Information Act (FOIA). A recent analysis found that the federal data organized by 
TRAC are more valid and reliable than actual government agency reports (Cordis \& Milyo, 2016). Once TRAC has obtained data through FOIA, a variety of statistical techniques are used to check and verify the data. The TRAC data are stripped of all identifiers, so they cannot be linked to specific cases or individuals.

TRAC data on federal cases from 2004-2015 were evaluated $(\mathrm{N}=3,628,287)$ with SPSS Software. Cross tabulations and frequencies were used to ascertain the patterns of prosecution across charge type and disposition for the past 11 years. According to the TRAC data, assistant U.S. Attorneys record the lead charge as the most serious charge in their judgment. Sometimes, the lead charge refers to the title and section of the U.S. Code, but in other cases, the code subsection may be included. In the SPSS analysis, charges were classified according to their frequency of use in three areas: public corruption, white collar crime, and organized crime. All other criminal cases not placed in one of these three categories were classified as "other." Case disposition was recorded across three different outcomes: not prosecuted, conviction, and not guilty. The "not prosecuted" code included cases designated as declined, immediately declined, dismissed without prejudice, or dismissed with prejudice. The "conviction" code was defined as convicted by jury, pleaded guilty, or pleaded nolo contendere. The "not guilty" code referred to a finding of not guilty by a jury.

Grounded theory approach best fits studies that seek to understand processes (Cresswell \& Poth, 2018). This study sought to understand decision making regarding the disposition of public corruption cases. With the use of purposive and snowball sampling, interviewees who had experience in public corruption cases were discovered through a general recruitment e-mail. Study and contact information was sent to former U.S. Attorneys and FBI agents. These interviewees selfidentified from the initial e-mails, and then, in a snowball approach, they suggested future interviewees. Researchers contacted the referred potential interviewees via e-mail, and if interested, they called or sent an e-mail to the researchers. Interviews were semi-structured with open-ended questions and lasted from 40 minutes to two and a half hours. Former U.S. Attorneys and assistant U.S. Attorneys $(n=22)$ had served in offices across the country and had experience prosecuting and/or supervising public corruption cases. Former FBI agents $(n=18)$ had served in different offices across the United States and had experience investigating multiple public corruption cases at all levels of government: local, state, and federal.

When using a grounded theory approach, researchers systematically collect and analyze data, usually obtained from interviews, to develop a framework that explains the process being studied (Cresswell \& Poth, 2018; Strauss \& Corbin, 1990). Inductive coding was used to complete an initial descriptive open coding to identify the category concerning decision points in public corruption cases. The initial descriptive coding identified the factual scenarios described by interviewees. Once the scenarios were coded descriptively, they were then coded according to different decisions in public corruption cases: declination and prosecution. A second analytical coding, also known as axial coding, categorized factors that led to a prosecution or to the declination of a prosecution (Cresswell \& Poth, 2018; Savin-Baden \& Major, 2013).

\section{RESULTS}

Data results include a comparison of declinations, prosecutions, convictions, and not guilty rulings across complex criminal litigation types (involving multiple variations of charges) versus other criminal litigation at the federal level. Additionally, interviews with former U.S. Attorneys 
Journal of Criminal Justice and Law

who oversaw and/or pursued public corruption cases reported on priorities and the decisionmaking process. Lastly, former investigators also discussed their perceptions of investigative and prosecution decisions.

\section{Case Disposition by Crime Type}

Table 1 contains TRAC data from 2004 to 2015. The table illustrates that public corruption cases were approximately one and a half times more likely to be declined $(62.3 \%)$ than prosecuted (37.7\%). When cases were prosecuted, the defendants were either found guilty by a jury or pleaded guilty (36.8\%). Fewer than $1 \%$ were found not guilty after prosecution. We compared public corruption cases with white collar crime and organized crime cases to assess similarities to and differences from other kinds of sophisticated crimes that often involve similar types of conduct (e.g., conspiracy, bribery, fraud). In contrast, the table shows that a smaller percentage of white collar crime cases than of public corruption cases resulted in no prosecution ( $54.5 \%$ vs $62.3 \%$ ) and correspondingly resulted in a greater proportion of convictions ( $45.2 \%$ vs $36.8 \%)$.

Interestingly, the pattern in organized crime cases is the opposite of the pattern in public corruption cases, as shown. The majority of cases are prosecuted (only $32.8 \%$ are not prosecuted, compared with $62.3 \%$ of public corruption cases). In addition, organized crime defendants are convicted nearly twice as often as public corruption defendants (66.8\% vs $36.8 \%$ ). The last crime type was an umbrella category that encompassed all those not included in the prior three crime categories. The table shows that for all other crime types, nearly 8 of every 10 cases were prosecuted $(77 \%)$. In fewer than a quarter of the cases in this category was prosecution declined (22.7\%). When cases went to court, the vast majority of defendants were convicted or pleaded guilty (99.7\%; only $0.3 \%$ were found not guilty). Consequently, prosecutors are most likely to obtain convictions or guilty pleas in "other" crimes, followed by organized crimes, then white collar crimes. Cases involving public officials also have the highest percentage of not guilty results $(0.9 \%)$.

Table 1: Case Disposition by Crime Type

\begin{tabular}{lrcrc}
\hline & N & $\begin{array}{r}\text { Not } \\
\text { Prosecuted }\end{array}$ & Conviction & Not Guilty \\
\hline Public Corruption & 19,117 & $62.30 \%$ & $36.80 \%$ & $.90 \%$ \\
White-Collar & 221,934 & 54.50 & 45.20 & .30 \\
Organized Crime & 130,006 & 66.80 & 32.80 & .40 \\
Other Cases & $1,656,123$ & 22.70 & 77.00 & .30 \\
\hline \multicolumn{4}{l}{} \\
\hline
\end{tabular}

According to these data, nearly two of every three referrals from agencies on public corruption are declined rather than prosecuted (62.3\%). White collar cases have a more even chance of being prosecuted $(54.5 \%)$. The pattern for organized crimes is nearly the opposite of the pattern for public corruption, in which for every three referrals, two are prosecuted (67.2\%). Fewer than a fourth of the "other" types of cases are declined for prosecution (22.7\%). 


\section{Decision-Making Process}

Through interviews with former U.S. Attorneys and former FBI investigators, the decisionmaking process behind these public corruption case decisions was elucidated. Many AUSAs described a balance to be struck when they were deciding on the approach to public corruption cases because of the complexity of the law, burden of proof, divisiveness in the political atmosphere, and public perception issues surrounding such prosecutions. This balancing act, illustrated in Figure 5, has resulted in a more focused attitude toward prosecuting public corruption at times and at others has been a reason to avoid such cases. As one AUSA put it, a public corruption case "is hard, but you can do it. But triage of cases must be done very carefully" (Interview A-14).

\section{To Decline or Not to Decline}

Former prosecutors and investigators repeatedly pointed to two main concerns that may lead to declining a case: personal or professional damage and public or political interests. Personal or professional damage consists of immediate consequences to themselves, consequences to their future endeavors, or legal ramifications. Public or political interests consist of excessive closeness to the parties being investigated or to an upcoming election, or a case too small to justify the resources used. Many prosecutors recognize that public corruption cases can come with stiff consequences. One former attorney described public corruption cases as "risky actions if you shoot and miss. When you go after people who cover their tracks and have the willingness to do whatever it costs, you, as an AUSA, have a lot to lose" (Interview A-03). Another AUSA explained, "These cases are time-consuming and dangerous" (Interview A-02). AUSAs are evaluated on the basis of their conviction rates, and public corruption cases can create a quandary for them. Negative evaluations were a common concern in these types of cases for both prosecutors and investigators. The concerns were not just about immediate career ramifications but also about future opportunities. One investigator shared the ramifications for one former AUSA:

Many AUSAs want to continue in the system. Many try to become judges. I had a friend who, as a deputy AUSA, prosecuted corruption cases. She was a finalist three or four times for judgeships. She came in a couple times and was questioned about the cases. Each time she was denied the judgeship. Politicians are saying you get us, we get you now. (Interview I-06)

Although there may be other reasons for the situation described, this belief resonated with several interviewees.

Another clear theme leading to the declination of cases is public or political interest. Sometimes, offices may have a conflict of interest and the case will need to be transferred to another office. In an interview, the process was described thus: "There were also cases where the office had to recuse itself. They were too close to the situation and Public Integrity (a section of the Department of Justice) would sometimes take it" (Interview A-21). A former AUSA reported on a case that the Department of Justice Public Integrity Section took from a local office; the case resulted in a finding of not guilty because of the jurors' local respect for the accused. In other cases, the amount of money involved may be too small to justify the resources used. One AUSA stated, 
Journal of Criminal Justice and Law

I also think location matters. It also happens in the suburbs, but there's a threshold issue. The threshold is at a certain money level. We look for big dollar value. Most of the time you don't have that in the suburbs. ... It's a very small amount [of money] but in the suburbs can swing a race. He could own a town for as little as $\$ 15,000-$ three members of a five-member counsel. The state attorney general may pursue cases we are not interested in taking. (Interview A21)

In other words, some cases are not big enough in financial terms to make a federal case of them.

At the other end of the spectrum, cases may be declined because "[t]here's lots of denial. People don't want to get involved" (Interview A-14). This interviewee went on to discuss why some offices (in different parts of the country) have higher rates of conviction in these types of cases than other offices:

A complaint I hear from friends is that U.S. Attorneys are in line for judgeships, and they do not want to make waves. Public corruption cases are particularly hard. It is a vocation to do them. You really have to love it. There is a lot of disappointment too in these cases. (Interview A-14)

Investigators reported this type of observation as well. One investigator described one AUSA:

The first prosecutor, he wanted to settle cases once a year. He would go with [major corporation and other contractors and reach an agreement through a settlement where they pay a fine. It makes a splash in the newspaper once a year. It looks like he's doing his job. They put the spin on it that they're not admitting to any wrongdoing. The settlement and fine end up being rolled into the overall price of the widgets. This is why we [need] to lock people up.

The first prosecutor, he was the only prosecutor working government fraud at the time. He would throw us out of his office and then talk to the corporation's attorney. He would call us in and say, "We have a settlement. You guys work too hard. You need to play golf more. Take [a] break, enjoy life." (Interview l-17)

Another investigator remarked, "First, if you go after the king, you have to kill him. Prosecutors are skittish to do a case." (Interview I-18)

\section{It Depends}

Some public corruption cases were easier to prosecute because of the nature of the underlying offense. Some prosecutors and investigators called these "low-hanging fruit cases" (Interviews A-10, A-11, I-15, and I-16). A former AUSA described these cases: "Miami primarily focused on police corruption because it was easy to prosecute ... police will just transport narcotics. It's easy corruption to find and prosecute" (Interview A-10). Another AUSA reported similar cases: "You have some drug cases in the Houston PD. We had 10 police officers. It happens easily. Those are the easy cases" (Interview A-11). These types of cases are easier to make because the burden 
is to show police officers accepted a bribe, took evidence, or protected a drug shipment. The corrupt acts are clear and easily relatable for the public. It is also clear to prove mens rea in such cases. To prove mens rea (criminal intent) in federal prosecutions, the government must show that the perpetrator knew that the actions were wrong and not innocent conduct (Elonis v. U.S., 2015). A-11 said about these cases, "In today's world you have tens of millions of low-hanging fruit cases."

At times, investigators expressed frustration about these types of cases and approaches. One investigator discussed a large police corruption case that spread throughout several districts but was told "to take the ten best cases in the district. So if you are the eleventh, twelfth, or thirteenth worst cop, you got a free ride because we're only focusing on the first ten. I never quite thought that was fair" (Interview I-16). Investigators discussed a desire to see wrongdoers pursued and punished.

\section{To Prosecute or to Persecute}

Some AUSAs shared this sentiment: "Every prosecutor wants public corruption cases because you want cases to make the greatest impact on the community. You need to get the biggest bang for your buck, and you want to prosecute the big person" (Interview A-15). One of the main purposes of such prosecutions is

... to deter the next person. For these types of convictions, the audience is people looking for vilification. Public corruption cases let people know the problems. The cases are a way to catch the wrongdoers, ways to punish them and a way to show "don't do it" to the public. (Interview A-22)

Whether to prosecute is a difficult decision because "public corruption are very hard cases to make. The line between honest graft, disgusting graft, to criminal [conduct] is sometimes hard to determine. You also have to show criminal intent, which is very hard" (Interview A-20). When prosecutors examine a public corruption investigation to determine charges, they consider several factors:

Does this case deserve the full weight of the government? What will serve the public in the long run? What do we expect from the Department of Justice? Is requiring compliance a way to get at this-is it sufficient to change the culture? (Interview A-18)

In other words,

You need to make sure you have a crime that occurred. And it has to be a crime that the jury cares about. Sometimes you have to make the jury care about the crime. First you start off with what did they do. What is the statute they're violating? And then you have to consider do the people care. You need to make clear these things so that the media can send a message to stop this behavior. (Interview A-01) 
Journal of Criminal Justice and Law

After all, AUSAs are making the issue a federal case. For such a matter, it must be of sufficient significance, usually reaching above a certain financial level $(\$ 10,000$ per occurrence) or be of a size sufficient to have a community-wide impact, such as the 13 school principals in the Detroit school system convicted in a vendor kickback scheme (Pérez-Peña, 2016).

Prosecutors always consider how the case will proceed in front of a jury. Since the ABSCAM videos (a major case in the 1980s involving an undercover sting operation that videotaped the selling of votes for cash, resulting in the conviction of seven congressmen), juries want to have concrete evidence. Many AUSAs shared these sentiments:

Generally [for] corruption at the state and local levels, DOJ and FBI do not proceed without aggressive behavior, money under the table, or money for exclusive access or resources-repeated payoffs. The standard point for prosecution to prove to the jury about corruption is through the money, video, and audiotapes. You have to show the people as crooked. (Interview A-05)

In public corruption cases, it is hard to show the corrupt acts without video. You need collaboration. (Interview A-10)

Additionally, corruption cases are difficult because "it is a process of corruption, not as straightforward as quid pro quo" (Interview A-08). Corruption can be nuanced and difficult to pinpoint, as explained by Interviewee A-11. "Juries have a hard time with public corruption cases. Inordinate influence is not illegal." Therefore, in addition to specific evidence, prosecutors must have a strategy

... to make the message simple in front of the jury. "We are owed" what should have come to the public [the public was defrauded, public money was stolen, etc.], and instead these guys were directed to themselves. They rationalize this behavior that they are owed for their job. Juries want to understand why these guys did the things they did. So the U.S. Attorney needs to give the juries the reasons why. In 99\% of the cases, these guys don't take the stand. (Interview A01)

Once the legal, theory, and evidence questions have been addressed, AUSAs consider how best to build the case; cooperating witnesses are key because paper-only cases are open to interpretation (Interview A-04). That is to say, more is needed than written documents because these records can have lawful explanations that can mask the corrupt action taking place. Additionally, proving mens rea in such cases is difficult because the government has to show the person's conduct as wrongful on its face (Abrams, Beale, \& Klein, 2017). But witnesses come with their issues. With witnesses,

... we ended up having to immunize people who had done some bad things. We looked at who is at the top. We then immunize people at the bottom. We looked at it as building blocks to move up the organization. Once you start, it flows, and you can see some real consequences. (Interview A-13) 
In many cases, witnesses are not good people. Witnesses seldom come to these cases with clean hands, which may hurt their credibility with juries. Moreover, public officials, especially those elected, have a certain amount of legitimacy with jurors, many of whom may have voted for them. Additionally, in many cases, elected officials attain some clout of local celebrity status; consider the former mayors of New York City (Ed Koch, Rudy Giuliani, and Michael Bloomberg) appearing as guest stars on shows (Adams, 2018) and being listed as local celebrities along with sports players, TV anchors, and other personalities (Busdeker, 2014). Others have written and discussed the phenomenon of politicians becoming celebrities in the last two decades (Domenech, 2018). The combination of celebrity status and the role of public official provides a certain legitimacy to these individuals, which prosecutors must overcome when presenting their cases. Moreover, unlike most other criminals, public officials usually "have better lawyers." (Interview A-20)

Public perception of the process can increase or detract from the legitimacy of the rule of law and is one of the last questions for prosecutors to address before deciding whether to indict. A complicating factor in these cases, unlike in other types of cases, is speculation about the AUSA's motivations. Whether or not prosecutors express any political motivations, they need to consider them. "Federal prosecutors are pushing the envelope on this one. DA says, 'No, we ain't.'" It's always a political component to these things" (Interview A-18). Some AUSAs would use other conduct statutes to convict public officials to avoid the label of politics:

We used the money laundering statute and fraud statutes as well. Many times, it was easier to use money laundering and fraud because it would result in the same sentence under the sentencing guidelines and had an easier road for prosecution. When it comes to public corruption cases it's always a question of proportionality. Courts would say to us that "you are overreaching items." (Interview A-18)

Overreach is a common complaint from the accused and their supporters. Seldom do AUSAs prosecuting white collar crimes or organized crimes become the target of calls of being a racist or leading a witch hunt.

People criticized me about going after him because he was Black. They would say it's always been this way in [the city]. This is how things occur. I don't know if it's true about past mayors but I'm here now and I can do something now. (Interview A-21)

Legitimacy of the process and the prosecution is key to ensure that violators of the public trust are held accountable.

\section{DISCUSSION}

Corruption cases are difficult, and they present long-term consequences even when investigations do not proceed to a prosecution. Politicians have lost elections because of innuendos and rumors about an investigation. Public corruption prosecutions are fraught with innuendos as cases resolve either to a declination or to a prosecution and conviction. In making 
their decisions about such cases, AUSAs face a variety of barriers to moving forward; these range from internal pressures regarding evaluations to external forces involving public perceptions, legitimacy concerns, attacks on attorneys' motivations, and legal strategy. For some AUSAs, politics is part of their world, and this is recognized by other AUSAs. "Certainly when Christie was Attorney General, 'it was political' [was used] as a defense not to do anything about the conduct" (Interview A-22). However, some offices have been experiencing a culture shift in which AUSAs have become "careers" (Interview A-21), and more AUSAs stay with the Office of the Attorney General for their entire career.

As more "careers" enter the field, an understanding of the decision-making process is important to maintain the legitimacy of the law. "Careers" are individuals who join the U.S. Attorney's office intending to spend most of their career serving the public interest. The interviews with former prosecutors and investigators referred to in previous sections have been used to develop a framework, presented in Figure 1, illustrating the three paths AUSAs and U.S. Attorneys may follow as they make their decisions.

Figure 1: Decision-Making Tree for U.S. Attorneys and Assistant U.S. Attorneys Evaluating the Prosecutability of Public Corruption Cases

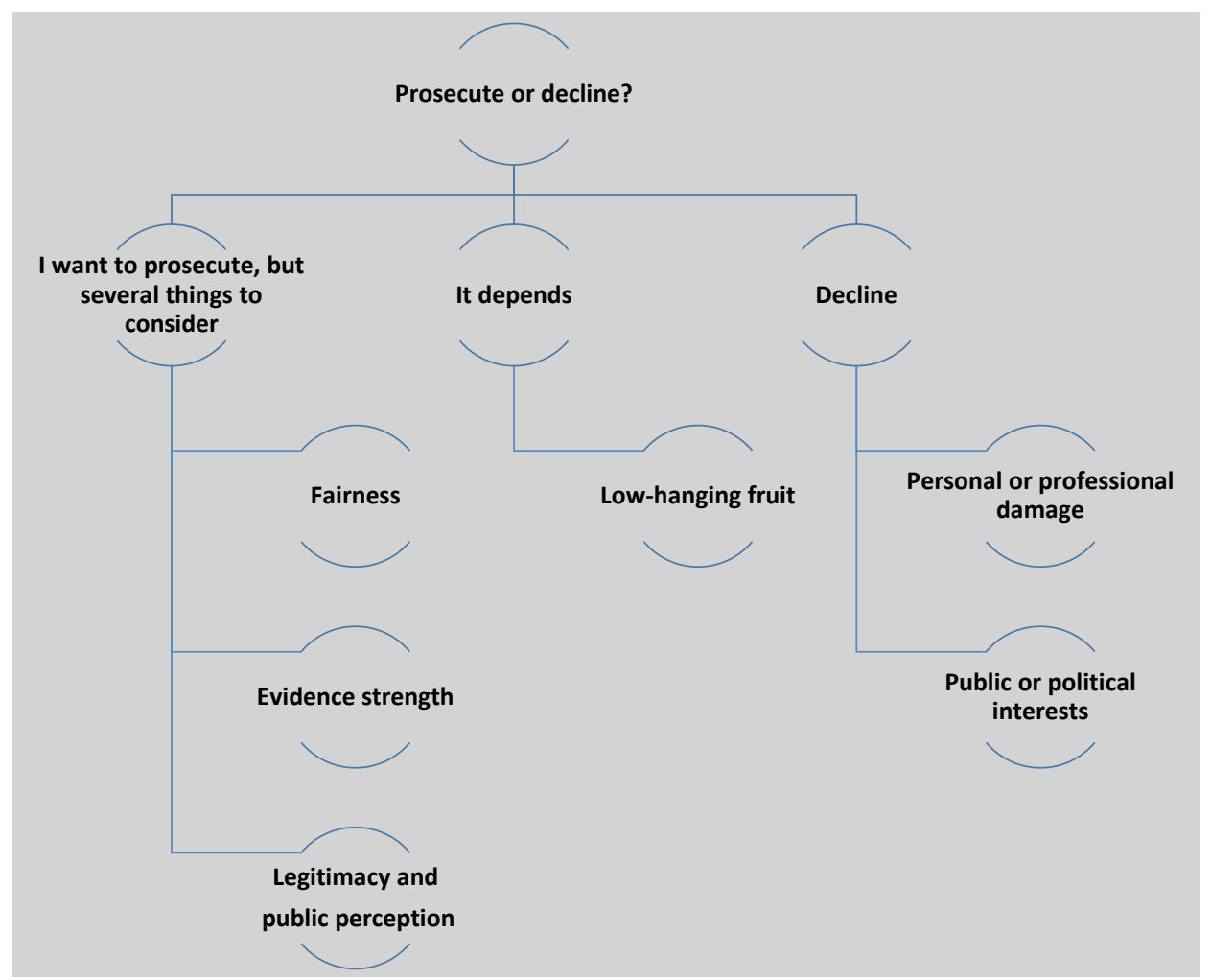


When U.S. Attorneys and/or AUSAs are leaning toward prosecution, the first consideration is fairness, particularly in regard to whether a behavior clearly falls outside appropriate ethical bounds or is simply "awful but lawful" (Interview A-21). Because federal law has been broadly defined, fairness is important to show that public officials clearly knew, or should have known, that their actions were an abuse of their lawful power. Issues of evidence influence whether a jury is likely to believe the witnesses, many whom present credibility concerns (e.g., have also committed crimes) and include the type of evidence used. Since ABSCAM, most juries expect to see a video of the action. Additionally, the prosecution needs to provide a convincing narrative of what happened because the elected defendants have some intrinsic legitimacy that others do not; some jurors may have helped to elect them to their positions.

Another layer to consider is the likelihood of conviction. Some prosecutors are more inclined to focus on an easy win from low-hanging fruit, such as corrupt police stealing evidence or protecting drug shipments, than on developing cases against higher-level corruption. Another concern is whether the prosecutions are sufficient to deter future corruption. Some prosecutors will focus on top counts and hope that those convictions will be sufficient to change the culture (e.g., prosecute the 10 worst police officers in a district).

The last areas to consider are the potential for personal or professional damage and public or political interests. These cases come with potentially significant ramifications: negative performance evaluations for prosecutors, extensive use of resources, and the possibility of longterm adverse effects on the individuals and offices involved. These cases require a year or longer to investigate and prosecute; therefore, some AUSAs may choose not to pursue them because a loss would adversely affect their annual review. Some consequences may be felt later in their careers as other public officials blackball them and limit their future career options. As for public or political interest concerns, some prosecutors may be too close to the area and should leave the decisions about prosecution to individuals with more distance. Others may be too close and in denial about the situation in that they can see themselves making similarly poor decisions without the necessary intent. These conflicts of interest may create additional barriers to prosecution. Finally, the facts must be sufficient to justify a federal case. Many offices have a dollar minimum, usually at least $\$ 10,000$, or the case must have significance for the community (e.g., police officers using their positions to coerce individuals for sex). As prosecutors travel this serpentine path, they must also consider political implications. Yet, for the few prosecutors who pursue these cases, politics does not appear to be a significant factor in their decision to prosecute or not. It is simply one of many elements to be considered.

This analysis has shown large differences in the investigative decisions and prosecution outcomes of public corruption, white collar crime, and organized crime cases. Data describing these cases illustrate that public corruption cases are more difficult to make and are more likely not to be prosecuted or result in convictions. Interviews with former federal prosecutors and investigators, experienced in public corruption cases, were used to elucidate the reasons why it is difficult to investigate and successfully prosecute public corruption. Multiple factors are considered in public corruption cases: legitimacy, difficulties in proving corrupt motivations, complexity of the cases, and the availability of talented defense representation. The investigation and prosecution of public corruption cases require incentivized and proactive work to ensure integrity in public life, despite the larger number of unsuccessful prosecutions for these than for other types of crimes. The investigative and prosecutorial effort against public corruption is 
Journal of Criminal Justice and Law

needed as both a deterrent and a prevention method (Boylan \& Long, 2003; Graycar \& Prenzler, 2013). The effort must be prioritized at the federal level because very few corruption prosecutions occur at the state level. The overwhelming majority of public corruption cases are undertaken by federal authorities (with targets at the federal, state, and local levels), so it is there that active investigations must be undertaken to ensure to the greatest extent possible that public officials are indeed acting in the public interest.

\section{Declaration of Conflicting Interests}

The author declares no potential conflicts of interest with respect to the research, authorship, and/or publication of this article.

Funding

The project was supported in part by Award No. 2015-IJ-CX-0007, awarded by the National Institute of Justice, Office of Justice Programs, U.S. Department of Justice. The opinions, findings, and conclusions or recommendations expressed in this publication are those of the author(s) and do not necessarily reflect those of the Department of Justice.

\section{Sources Cited}

\section{Articles, Books, and Reports}

Abrams, N., Beale, S. S., \& Klein, S. R. (2017). Supplement to Federal Criminal Law and its Enforcement (6th ed.) St. Paul, MN: West Academic Publishing.

Adams, D. (2018, February 14, 2018). How Pete Buttigieg crushed it on NPR's 'Wait ...Don't Tell Me!' Indy Star.

Albanese, J. S., \& Artello, K. (2018). Focusing anti-corruption efforts more effectively: An empirical look at offender motivation - positive, classical, structural and ethical approaches. Advances in Applied Sociology, 8(6), 471-485.

Albanese, J. S., Artello, K., \& Nguyen, L. T. (2019). Distinguishing corruption in law and practice: Empirically separating conviction charges from underlying behaviors. Public Integrity, 21(1), 22-37.

Alt, J. E., \& Lassen, D. D. (2012). Enforcement and public corruption: Evidence from the American States. The Journal of Law, Economics, and Organization, 30(2), 306-338.

Becvar, T. M. (2013). When does sleaze become a crime? Redefining honest service fraud after Skilling v. United States. Chicago-Kent Law Review, 88(2), 593-620.

Beale, S. S. (2009). Rethinking the identity and role of United States Attorneys. Ohio State Journal of Criminal Law, 6, 369-439.

Boylan, R. T., \& Long, C. X. (2003). Measuring public corruption in the American states: A survey of state house reporters. State Politics \& Policy Quarterly, 3, 420-438.

Busdeker, J. (2014, September 30). Ranking 51 Central Florida celebrities. Orlando Sentinel.

Bushway, S. D., \& Forst, B. (2013). Studying discretion in the processes that generate criminal justice sanctions. Justice Quarterly, 30, 199-222.

Carpenter, D. P. (2001). The forging of bureaucratic autonomy. Princeton, NJ: Princeton University Press.

Center for the Advancement of Public Integrity, Columbia Law School. (2017). A guide to commonly used federal statutes in corruption cases. 
Cordis, A. S., \& Milyo, J. (2016). Measuring public corruption in the United States: Evidence from administrative records from federal prosecutions. Public Integrity, 18(2), 127-148.

Cresswell, J. W., \& Poth, C. N. (2018). Qualitative inquiry \& research design: Choosing among five approaches. Washington, DC: Sage Publishing.

Domenech, B. (2018, December 5). How politicians became celebrities, with Matt Bai. The federalist radio hour.

Gordon, S. C. (2009). Assessing partisan bias in federal public corruption prosecutions. American Political Science Review, 103(4), 534-554.

Gottschalk, P. (2016). Investigating fraud and corruption: Characteristics of white-collar criminals. Journal of Forensic Science \& Criminal Investigation, 1(2), 555-560.

Graycar, A., \& Prenzler, T. (2013). Understanding and preventing corruption. New York, NY: Palgrave Macmillan.

Haberman, M., \& Savage, C. (2017, March 11). U.S. Attorney Preet Bharara says he was fired after refusing to quit. The New York Times.

Hartley, R. D., \& Tillyer, R. (2018). Examining prosecutorial discretion in federal criminal cases: Legal and extra-legal determinants of declination and charge change decisions. Justice Quarterly, 35(7), 1195-1225.

Johnston, M. (2010). Setting the integrity agenda for Inspectors General. Public Integrity, 12(4), 315-324.

Kutateladze, B. L., Andiloro, N. R., Johnson, B. D., \& Spohn, C. (2014). Cumulative disadvantage: Examining racial and ethnic disparity in prosecution and sentencing. Criminology, 52(3), 514551.

Lawson-Remer, A. (2009). Rightful prosecution or wrongful persecution? Abuse of Honest Services Fraud for political purpose. Southern California Law Review, 82(6), 1289-1334.

McGuire, J. M. (2011, September). Ever increasing hurdles. International Financial Law Review, p. 89.

Pavlik, J. B. (2017). Political importance and its relation to the federal prosecution of public corruption. Constitutional Political Economy, 28(4), 346-372.

Pérez-Peña, R. (2016, March 29). 13 Detroit school principals charged in vendor kickback scheme. The New York Times.

Ramirez, M. K. (2013). Criminal affirmance: Going beyond the deterrence paradigm to examine the social meaning of declining prosecution of elite crime. Connecticut Law Review, 45(3), 865931.

Roberts, R. (2012). The Supreme Court and federal prosecution of state and local government corruption. Public Integrity, 14(4), 399-412.

Roebuck, J. (2016, December 12). Former Philadelphia Congressman Chaka Fattah sentenced to 10 years in prison. The Philadelphia Inquirer.

Rose-Ackerman, S., \& Palikfa, B. J. (2016). Corruption and government: Causes, consequences, and reform (2nd ed.). Cambridge, UK: Cambridge University Press.

Sanyshyn, A. (2017). Public corruption. American Criminal Law Review, 54(4), 1673-1726.

Savage, C., \& Haberman, M. (2017, March 10). Trump abruptly orders 46 Obama-era prosecutors to resign. The New York Times.

Savin-Baden, M., \& Major, C. H. (2013). Qualitative research: The essential guide to theory and practice. London, U.K.: Taylor \& Francis. 
Journal of Criminal Justice and Law Official Journal of the Law and Public Policy Section of the Academy of Criminal Justice Sciences

Singh, D., Catsambas, M., Flynn, H., Kot, Y., \& Mayo, W. (2017). Racketeer influenced and corrupt organizations. American Criminal Law Review, 54(4), 1727-1785.

Spohn, C. (2018). Reflections on the exercise of prosecutorial discretion 50 years after publication of The Challenge of Crime in a Free Society. Criminology \& Public Policy, 17(2), 321-340.

Strauss, A., \& Corbin, J. M. (1990). Basics of qualitative research: Grounded theory procedures and techniques. Thousand Oaks, CA: Sage Publications.

Transparency International. (2017). What is corruption?

U.S. Department of Justice. (2017, January 12). Navy officer sentenced to 30 months in expanding bribery and fraud investigation (Press Release No. 17-053). Washington, DC: Office of Public Affairs.

U.S. Department of Justice. (2018, April 19). Fraud and public corruption. Washington, DC: United States Attorney's Office.

Weiser, B. (2017, March 24). Should prosecutors chastise those they don't charge? The New York Times.

World Bank. (2019). Combating corruption.

\section{Case Cited}

Elonis v. U.S., 135 S. Ct. 2001 (2015).

\section{Authors' Biographies}

Kristine Artello, JD, PhD, does research that broadly examines how certain behaviors or events become defined and/or responded to in law and policy. Recently, she and Dr. Jay Albanese have published several articles on public corruption case investigation process and prosecution. She currently is an associate professor at the VCU Wilder School, where she primarily teaches law and public policy classes.

Jay Albanese, PhD, is Professor in the Wilder School of Government \& Public Affairs at Virginia Commonwealth University. He received the Ph.D. from Rutgers University School of Criminal Justice. He served as Chief of the International Center at the National Institute of Justice (NIJ), the research arm of the U.S. Department of Justice. Dr. Albanese is author of many articles, and is author and editor of 20 books. 